RESEARCH

\title{
democracy in troubled times
}

\author{
yves mény
}

European University Institute, Badia Fiesolana, Via dei Roccettini 9, I-50014, San Domenico di Fiesole (FI), Italy

doi: $10.1057 /$ eps.2010.10

\begin{abstract}
Democracies are fragile constructions. The apparently overwhelming expansion of democratic regimes should not, however, hide their intrinsic weaknesses. The paper examines how five (hypo)theses proposed by the author 10 years ago are still valuable instruments of analysis in periods of troubled times. The discrepancy between aspirations, programmes and the harsh reality of today is examined in the background of the Europeanisation and globalisation processes.
\end{abstract}

Keywords democracy; crisis; globalisation; Europeanisation of politics and policies

\section{$\mathrm{T}$} o put it mildly, we are going through exciting times. ${ }^{1}$ There is no risk of being bored, as the magnitude and the speed of change across the world is such that the majority of people are overwhelmed by this ongoing 'great transformation'. Twenty years ago, the western world was rejoicing and dancing over the ruins of the Berlin Wall. The symbol of hatred, oppression and communism had fallen apart, opening new horizons and hopes not only for Germany but also for the whole of Europe as well as for many countries where dictators used to manipulate the division of the world in order to raise the stakes between the dominant powers.

To many this event appeared to be the unchallenged victory of the market and democracy. Indeed the collapse of the former communist regimes was twofold: the political failure was further exacerbated by an economic collapse. The socialist utopia in Soviet hands was only a nightmare. However, the supremacy of western values did not lead to moderation, but the opposite. The ayatollahs of the market took over and have dominated the debate for the past 20 years. The new creed was that markets were never more efficient than when freed of any public intervention. Exchanges and trade expanded dramatically and the pressure resulting from increased international competition contributed to the dismantlement of the social democrat consensus and institutions, in particular in the so-called Old Europe. The world became more global as it used to be - albeit in a very different way - at the end of the nineteenth century. 
Progress in transport and communication were the privileged instruments of the first globalisation processes allowing for discoveries, economic exchanges and political control through the domination of the rest of the world by the Europeans. This first modern globalisation was characterised by the conquest of vast empires and the expansion of commerce thanks to technological innovation. Unfortunately, the contradictions, tensions and conflicts inherent in this expansion brought conflicts and wars in many parts of the world. The First World War was the testimony of this globalisation and at the same time its fatal blow.

It is only recently that globalisation has come back in full force after many years of slow, incremental elimination of trade and exchange barriers. Everything has become global and, once again, technological innovation - in this case the internet - and the low costs of transportation have been instrumental in transforming the aspiration to universality into reality. Everything has become global: not only the market of goods, but also the circulation of people, ideas, values, money. Problems and issues have followed the same pattern: global warming, terrorism, mafias, trafficking of drugs or human beings are a matter of concern worldwide. In fact, the globalisation phenomenon escaped quickly from the hands of its masterminds and initiators, taking a direction and a speed that nobody was really able to control.

Twenty years later, the 1989 triumphant attitude has gone. The utopian illusion of creating a perfect world by imposing communism has been rejoined by the collapse of the neo-liberal creed, the faith in market's capacity to regulate itself without the intervention of public authorities. Market failures are in front of us and States have to step in again.

It has often been argued that democracy and the market have gone hand in hand because of their common properties: the

\section{'...the 1989 triumphant attitude has gone.'}

same preconditions (individualism, freedom, rights) have been necessary for the development of both. In the same vein, capitalism and democracy bloomed, at least initially, within the same overlapping spaces. Democracy was born and developed within the Nation-State and many still argue - in particular in relation to the development of the EU - that it can do so only within that territorial space.

Over time these overlapping features partially lost their relevance, but the discrepancies between global markets and national democracies were hidden by the fact that initially less than a dozen states were controlling most of the world. However, after the First and Second World Wars, it became clear that some compensatory instruments were needed to control and limit, at least partially, some of these imbalances. Multilateral organisations tried to address and redress the growing gap between the space of the market and the space of politics. In many ways the only ambitious attempt to face this dilemma by going beyond multilateralism has been the European integration project, at least in its initial phase.

It is in this context that I would like to revisit five hypotheses on democracy and its future that I presented in 1999 on the occasion of a meeting in Florence of liberal and social democrat leaders, when Tony Blair and Bill Clinton were trying to convince Lionel Jospin, Gerard Schroeder and Massimo D'Alema that the 'Third Way' was the solution for the new world in the making.

Obviously, as somebody once said 'it is difficult to make prophecies, especially about the future'. In addition to this intrinsic difficulty, it should be underlined that at the time, nobody had the slightest doubt about the superiority of 
our democratic rules, values and institutions. The limits of this blind faith were dramatically illustrated 3 years later by the war in Iraq.

So today my objective will be to re-examine and critically assess the five theses/hypotheses that I then formulated, with the benefit of 10 years of retrospective knowledge and development and in the light of the present economic and financial earthquake, which is affecting everybody.

\section{THESIS 1}

The absence of any alternative to the western political model has eliminated external threats, but enhanced internal challenges. Democratic consolidation concerns not just the new democracies, but all democracies.

My point was that the elimination of competing alternatives such as 'socialist democracy' had both strengthened and weakened democratic regimes. The weakening or disappearance of counter-models has made more obvious and less acceptable the flaws and defects of the western democracies. I wrote at the time ${ }^{2}$

the main challenge for democracy in the coming century is not an alternative still to emerge but the indifference of citizens. Another expression, unfortunately experienced between the wars, of dissatisfaction with the democratic system can be the rejection of the moderate forms of the democratic system as we know them in favour of radical popular forms: populism, extremisms of right or left (...). Democracy might thus remain the universal reference scheme while being seriously threatened here or there. In a recent book entitle provocatively Democracy incorporated. Managed democracy and the spectre of inverted totalitarianism, Sheldon Wolin (2008: 196) argues that

democracy in America and elsewhere is affected by a degeneration resulting from a mix of popular indifference, media suasion, domination of corporate interests and obsession for security and control.

This diagnosis strongly influenced by the observation of the Bush years links up in some ways with the Tocquevillian pessimism about the transformation of democratic regimes into 'soft' authoritarian regimes based on the passive consensus of the people. Wolin goes as far as qualifying this evolution as 'inverted totalitarianism' that is a system which 'thrives on disaggregation, or a citizenry who, ideally are self-reliant, competitive, certified by standard testing, but equally fearful of an economy subject to sudden downturns and of terrorists who strike without warning.

At the time I also emphasised that the risks for democracy would be 'the greater if collective issues have been taken out of politics to be dealt with in other arenas'. This statement picked up part of the problem underlying the growing dissatisfaction with the functioning of party democracy but in fact missed some developments or underestimated others. At the time, I had not perceived that challenges to democracy could result from an alliance between external and internal forces as has often happened in history. Ideas and movements are not bound by frontiers and nothing is purely internal or external as both the development of liberal democracies in the nineteenth century and of socialist regimes in the twentieth century testifies. Today, the most obvious example of this entanglement is given by terrorist activities in which external and internal ingredients are intimately related. In the same vein, my reference to the pressure or influence of the international community in favour of democracy was based on previous activism, notably the defence of human 
rights or by integrating new and fragile democracies under protective umbrellas such as the European community. I had completely overlooked at the time that a democratic nation could deliberately go to war with the excuse of imposing democracy on a foreign country.

\section{THESIS 2}

Western-type democracy and the market are historically linked (even if not totally inseparable). But the democracies do not have suitable instruments for coping with a major economic and social crisis.

This point was partially inspired by the dramatic experience of Europe after the First World War. The conflict put a dramatic end to the first wave of globalisation and was followed by the dismantlement of empires and the burgeoning of new Nation-States structured along the lines of existing democratic traditions. Their failure was dramatic and fast.

The democratic reconstruction after the Second World War was also a refoundation: the welfare state after the warfare state. But in my 1999 paper, I emphasised that 'Western Welfare State systems have exhausted their capacities and their resources. Having grown to excess, they are scarcely able to give anymore. Let us crudely confess, I added: in the face of an economic depression, that will be all the more devastating since the planet today is in a situation of total interdependency, there is not yet any economic or financial "safety plan", still less political remedy except hoping in the clairvoyance of the elites and the wisdom or good sense of the citizens. From past experiences one lesson can, alas, be drawn: crises catch unprepared not just political practitioners, but also theorists and experts. It is often crises that give rise not just to new economic and social conditions, but also to new
'I had completely overlooked at the time that a democratic nation could deliberately go to war with the excuse of imposing democracy on a foreign country.'

\author{
'What was then \\ considered as a \\ hypothesis is today a \\ rather tragic reality.'
}

paradigms, new intellectual and practical instruments. What was yesterday unthinkable (and unthought-of) suddenly becomes possible and feasible'.

Ten years later, in 2009, I will certainly not withdraw a single word, although now the landscape is quite different. What was then considered as a hypothesis is today a rather tragic reality. We are, however, far from having a full understanding of the way this crisis will unfold. We know for sure that the neo-liberal zealots, with a few exceptions such as the President of the Czech Republic, have to adopt a lower profile. Faced with the collapse of the financial markets followed by the crisis of the real economy it becomes difficult to pretend that the invisible hand of self-regulated markets is able by itself to guarantee a smooth running of the global economies. We are more aware that no market can function properly without some form of regulation. We better understand that the discrepancy between national political territories and global economic space is a contradiction to be urgently addressed and tackled. Some new orientations and proposals are already on the table such as those emanating from the London and Pittsburgh G20 meetings. But as a century 
of experience of international organisations teaches us, cooperation and dialogue between sovereign states is not enough. These kinds of instruments can at best deal with the international relations between states. There are poor and mediocre instruments for addressing issues that have moved from national polities to the global level. A level that has reality and substance in terms of goods, services, resources, money and ideas, but is still a no man's land in political terms. They are also unable to deal with the problems faced by democratic systems at the national level. The impact of the new crisis will be felt everywhere but might be more dramatic in countries where democracy is still a recent and fragile development.

\section{THESIS 3}

The trend is for the democratic system to evolve towards universality, but its forms must allow a diversity of models and enable cultural particularisms to be accommodated.

This thesis starts from the observation that democracy has enormously expanded over the past 30 years or so. Democracy is a system under permanent tension, an ever changing and improving model of political organisation. By its very conception, democracy is a system allowing and calling for dissatisfaction and improvement. The capacity of democracies to survive and flourish is, on the one hand, to permit dissent but at the same time to react in a sufficiently rapid and efficient way in order to accommodate and integrate the elements that otherwise could be self-destructive. As Johan Olsen has underlined, democracies are 'organised' democracies meaning that the more they are institutionalised, the more resistance to change increases. But Olsen (2009: 12) also emphasises that 'Institutions are not

\section{'...it is time for westerners to disentangle what might be considered as the democratic fundamentals'}

static'. 'In democracies, change is usually incremental, but it can also be pathbreaking, with a sharp departure from existing practice'.

In other words, democracy is an unfinished business. But, too often, existing democracies, in particular those that believe in their missionary vocation, tend to consider that their system as it stands is the ideal model to be applied elsewhere. This can be observed, for instance, in former colonized countries where the colonial empire has granted, together with independence, a ready-made kit for democracy based on a rather standardised 'cut and paste' transfer. There is obviously some rationale in such a strategy.

But there are also drawbacks. First, the richness of historical development that took place in the first democratic regimes tends to be considered as irrelevant when democracy is created from scratch. Second, this attitude overlooks the fact that all democracies are 'impure', that is, made up of universal democratic values on the one hand (such as fundamental rights or universal suffrage), but also of elements that are not democratic by themselves but part of the checks and balances within the constitution. Some of these checks might be democratic (the use of referenda for instance to counterweight the parliaments). Some might be literally anti-democratic, but considered as crucial components in order to avoid the tyranny of the majority. The survival of the monarchy or the existence of second chambers is in fact part of the democratic construction in many western countries. 
So, it is time for westerners to disentangle what might be considered as the democratic fundamentals, and what can be left to the specificity and peculiarity of every system. As the great Indian economist Amartya Sen has argued, every society might include in its tradition, culture and values some democratic elements. As experience and observation teach us, elections and parties are not the alpha and omega of democratic politics. Democratic teachers and preachers from the western world should be more modest in their plea and pressure for democratisation throughout the world. After all, how many European countries could be defined as democracies 50 years ago? Democracy requires dedication and care but also time. It needs adjustment to local cultures and traditions. An elected judiciary might be contemplated as indispensable in some countries, while others might prefer an independent system based on a civil service type organisation. In many cases the frontier between the 'democratically imperfect' and the 'unacceptably un-democratic' is thin and calls for debate and dialogue rather than proclamation of absolute truth and excommunications.

This state of mind is of particular importance today as we are in the middle of a crisis that affects not only the prosperity but also the foundations of our societies. Limiting democracy to political parties and electoral processes, as still happens in some new 'democratic systems', is untenable. Expanding social rights as the western societies did over the past century is not affordable anymore. Strengthening popular participation is a remedy that does not go far except to enlarge slightly the composition of the political elites. There is certainly one issue on the agenda for which we do not yet have a fully fleshed answer: how to reconcile democracy and globalisation?

\section{THESIS 4}

The democracy of the future will have to be able to reconcile the contradictions between its rootedness in the NationState and the transfer of powers to universal but sectoralized authorities.

My argument here was that the daily life of citizens across the world was deeply affected by the development of the international dimension in its triple form: globalisation, regionalisation and transnational phenomena. I underlined that in the past, globalisation was for a large part the by-product of unilateral action by a few dominant actors. Some powerful countries were able to dominate and subdue the rest of the world. The extent of this domination can be illustrated by some very basic and simple data. France before the First World War had only a dozen embassies in the world and a few additional minor legations. The situation was similar among the so-called great powers when international law was the law of 'civilised nations'. Globalisation was a matter for the benefit of a few. Britain was still ruling the waves, and there was no apparent contradiction between the existing democratic regimes and a global system, which was a simple by-product of these dominant countries.

Today globalisation is a multilateral, organised and partially institutionalised phenomenon on the one hand, but at the same time an ongoing process whose development seems out of control. Everybody is trapped in and unable to master the unexpected consequences propelled from Pandora's Box. At first sight, the globalisation process seems to be framed by multilateral organisations set up after the Second World War such as the World Bank, the IMF, the WTO and many other institutions alike. But this multilateralism is partially obsolete, partially incomplete and not in line with the qualitative change induced by the endless expansion of 
the globalisation processes. It is obsolete because it reflects the post-war equilibrium and not the present balance of economic and political power; it is incomplete as the regulatory framework is either too loose (as in the case of environment) or barely existing (as in the case of financial regulation). But the main issue lies in a considerable reduction of the democratic space as national institutions feel unable to act on these issues that are beyond the power of national authorities. Part of the popular frustration and the populist protest is triggered by this discrepancy between political expectations and economic constraints. Kevin O'Rourke (2009), an Irish economist, has made an interesting point on this question. Taking advantage of the previous globalisation experiences he insists that income distribution matters not just for its own sake (...) but also because of its importance for the political sustainability of liberal international trade regimes'. The possibility of a populist backlash against globalisation, he writes, seems to be rising all the time now, as voters discover more and more facts about the operation of tax havens, the consequences of 'regulatory arbitrage' and the risks of unrestricted international capital flows. The obvious danger is that the additional pressures created by the macroeconomic crisis will be exploited by interests that have been becoming increasingly hostile to 'globalisation' in any case. 'If the leaders of democratic societies wish to retain the undoubted benefits of open international markets, they will need to take greater notice of the interests of those who are being left behind'.

O'Rourke underlines as an example of this past trade-off, the European regulations and schemes that assured protection to the workers while facilitating international exchanges. If nothing is done, insists O'Rourke, 'it is clear that we could be headed for a political "perfect storm" unless governments can provide voters with reassurances that the market economy in general and the international market economy in particular can be made to work for them'.

It is here that political imagination and engineering has to step in. Political multilateralism, in the way in which it has expanded since the Second World War, will not be enough. Shifting from G8 to G20 might satisfy 12 additional states, but will not fully address the issue. International organisations have to be redesigned with a different kind of mindset. The key question is not only to ensure a more multilateral course of action, but also to push democratic principles further upwards as has been partially attempted at the regional level in the case of the European Union. This might sound foolish and utopian but we should not forget the paradigm shift that took place at the time of the American and French revolutions. Up to that time, democracy was perceived as an ideal, but applicable only to minuscule states. The combination of the democratic and representative principles was the key factor that allowed the development of democracy in large political systems. Mutatis mutandis, we are invited to discover the same revolutionary transformation in order to avoid the danger that democracy, at the national level and as we know it, becomes little by little an empty shell, void of substance. There is no blueprint or a ready-made solution. But, indeed, if we wish to prevent an economic crisis that is similar in magnitude to the 1929 Great Depression producing similar effects, it is urgent to redesign our mental maps and review our referential paradigms.

\section{THESIS 5}

Globalisation calls into question a number of concepts, perceptions and interests shaped by the historical merger

yves mény european political science: 92010 
between the Nation State and the democratic arena. A new definition of democratic values is inevitable.

The emergence of regional and global actors beyond the Nation-State has triggered an intense debate on the 'democratic deficit' issue. Some of those who express their scepticism about creating a democratic space at the European level argue that the major impediment to the creation of a European democracy is the lack of a demos. This argument sounds familiar to the French who have been educated with the view that the French identity/nation/state have developed harmoniously together. In fact, 'France' and 'the French' is a construction resulting from long battles, conflicts, imposition of power, etc. ... There is no doubt that there is a French people. But it is an outcome rather than a given. The same can be said of most countries be they democratic or not. Invoking the heterogeneity of the European demos to argue that democracy is impossible beyond the Nation-State is historically and empirically wrong. As Benedict Anderson put it, nations are 'imagined communities'. Europe could become an 'imagined community' too, but it requires effort, time and direction. Very few communities are 'natural'. Even the basic one, the family, is subject to a great variety of definitions across time and space.

Beyond this crucial point and whatever position we might have on this question, an objective fact remains: the traditional overlap or coherence between economic and political space is broken. In most countries, until the nineteenth century, a major effort was made in order to ensure this coherence by eliminating internal barriers be they economic, fiscal, linguistic or political. France, Germany and Italy are major illustrations of that trend. Elsewhere it is only recently that such a result has been reached at a very high cost, through the massive displacement

\section{'Europe could become an \\ "imagined community" too, but it requires effort, time and direction.'}

of population, the redesign of frontiers, wars, etc. But having barely reached this objective, the nation/state/democracy construction has been challenged by regionalisation, as in the European case, or by globalisation. This evolution brings a dramatic change.

Today, many matters have been transferred to supranational bodies or authorities; others are beyond the capacity of national decision-makers. Rather than being complete as it used to be, the reach of national politics has been reduced either through transfers of competences or through shared responsibilities. This new division of labour is problematic, as politics in democratic settings was often an art of compensating or offsetting costs of one kind with benefits elsewhere. Today this has become difficult or sometimes impossible. Economic regulations for instance are made at the European level, but the European institutions have barely any means to compensate the losers or to tax the winners in order to redistribute benefits and pain. On the other hand, national authorities are fully in charge of the welfare of their citizens, but their margin of manoeuvre is limited by competition within the Union that some qualify as a 'race to the bottom'.

The EU is a huge regulatory machine that has to guarantee the four freedoms set up by the Treaties, or the principle of equal treatment within the Union. But equalising social conditions is not its business and even less solidarity between the EU members, even if some initiatives were initially put in place with this goal in mind by pooling policies and resources. This was the case for the Coal and Steel Community, the Common Agricultural 
Policy (CAP) and the structural funds. But this aim is challenged more and more. Margaret Thatcher's cry 'I want my money back' was the most vocal expression of a feeling shared by most if not all Member-States.

Solidarity that has been thrown out of the door by the neo-liberal approach of the past years might come back through the window, given the present economic and financial conditions of many countries, in particular in Eastern Europe. But this so-called solidarity is a fig leaf hiding more egoistic concerns. The rescue of Member-States, if some need to be bailed out, will surface as an expression of fear and necessity. Avoiding a domino effect is the main concern. Market is the domain of self-interest not of solidarity. This is why an institution with political objectives, as the EU claims to have, cannot be built up only on the basis of market regulations. It is a contradiction in terms.

Majone has shown that the EU as a regulatory state does not need to be democratised because only redistribution policies would require decisions by a democratic representative body. As somebody once put it 'A Zollverein is not a polity'. But history also teaches us that a monetary union and customs union without political institutions will not last long, unless they evolve towards more political integration. Europe from this point of view is at the crossroads. My assumption, that some might find excessively pessimistic, is that Europe will not be able to hold together if further political integration does not remain on the agenda. It is not a matter of political preference, but of feasibility and longterm sustainability. The crisis from this point of view might cut the Gordian knot. As it deepens, tensions within the single market, the Eurozone, the Union as a whole and the Eurozone will grow. Any serious incident on the road could trigger unpredictable consequences. It is, unfor-
'Solidarity that has been thrown out of the door by the neo-liberal approach of the past years might come back through the window,

tunately, the most likely scenario, given that self-interest remains at the top of the agenda and policymakers and politicians have failed to secure wide and strong popular support for Europe over the past 20 years. The European elections in June have been the latest illustration of this state of affairs.

The alternative could (and in my view should) be to strengthen Europe both politically and institutionally. But I have to confess that under the present conditions, this is wishful thinking. I do not perceive among the political elites and the citizens a 'surge' in favour of such an option. The price to be paid for the vertical division between politics (at the national level) and policies (at the regional or global level) is indeed very high. Kevin O'Rourke (2009) states that 'it would be foolish to assume that a commitment to economic multilateralism will be effective without a commitment to political multilateralism and international law more generally'. I fully agree, but at the same time I believe it will be necessary to go further: first by transforming Europe into a democratic postnational space, then by developing, at the global level, a fully fleshed system of the rule of law, and not only a pure powerbased type of relationship. This might sound utopian and unrealistic and for sure we are far from having a good understanding of how and when such developments could take place.

In conclusion, let me repeat and insist that we are in a situation similar to 1787 or 1789 when democracy was deemed to be reserved to tiny political systems. 
The challenge of our times is at least as difficult and as unpredictable. But in my view, there are few alternatives if, as commented by a French political advisor recently, we wish to avoid not only revisiting the economics textbooks of the 1930s but, worse, the history textbooks of that time.

\section{Notes}

1 This is a revised version of the Stein Rokkan Lecture delivered at the ECPR's Joint Sessions, 14-18 April 2009.

2 This paper was published in a modified version in The Global Third Way Debate (Anthony, 2001: pp. 259-69).

\section{References}

Anthony, G (ed.) (2001) The Global Third Way Debate, Cambridge: Polity Press; Malden MA: Blackwell, pp. 259-269.

Olsen, J.P. (2009) 'Change and continuity: an institutional approach to institutions of democratic government', European Political Science Review 1(1): 3-32.

O'Rourke, K. (2009) Politics and Trade: Lessons From Past Globalisations, Breugel: Bruegel Essay and Lecture Series.

Wolin, S.S. (2008) Democracy Incorporated: Managed Democracy and the Spectre of Inverted Totalitarianism, Princeton: Princeton University Press.

\section{About the author}

Professor Emeritus Yves Mény President of the European University Institute in Florence, Italy, is the author of La corruption de la République, Paris, Fayard (1992), co-author (with Daniele Caramani) of Challenges to Consensual Politics. Democracy, Identity, and Populist Protest in the Alpine Region, Brussels, P.I.E. Peter Lang (2005) and together with Yves Surel of Democracies and The Populist Challenge, (co-edited with Y. Surel), London, Palgrave (2002). 